Matgorzata ABASSY

Uniwersytet Jagielloński

malgorzata.abassy@uj.edu.pl

\title{
SYBERIA W PAMIĘCI ZESŁAŃCÓW I ICH DZIECI
}

\section{STUDIUM PRZYPADKU RODZINY ŻUKOWSKICH}

ABSTRACT Syberia in the Memories of the Polish Exiles. Case Study of the Zhukovsky Family

The story of the exiles of the Zhukovsky family is presented in the paper. Analyses were based on interviews with Dagmara, the daughter, two documentaries: On memory paths and Crust of Bread, and a manuscript written on the basis of Danuta and Bogusław recollections by Dagmara. Hypotheses of the paper were the following: a story of a family is the history of a nation. There is a parallel between historical events and an individual's fate. The ancestors, need to tell one's story and the descendants' need to hear it are reciprocal ones and can be interpreted as a cultural mechanism of incorporation new texts into a culture memory. On an individual level it gives rise to the feeling of dignity and power. Marianne Hirsch's theory of post-memory and Yury Lotman's concept of 'remembering - forgetting' mechanism were utilized to present and interpret memories of Boguslav and Danuta Zhukovsky and their descendant - Dagmara. The reasons for reaching into the past and coming back to Syberia were also analysed.

Keywords: Syberia, memory, family, case study

Słowa kluczowe: Syberia, pamięć, rodzina, studium przypadku 
$\mathrm{C}$ elem niniejszego artykułu jest refleksja nad potrzebą pamiętania i przekazywania doświadczenia traumatycznych wydarzeń kolejnym pokoleniom, a także potrzeba płynąca ze strony dzieci, by zaczerpnąć z doświadczenia rodziców i zbudować na jego podstawie poczucie siły, godności i świadomości najważniejszych wartości, które z kolei można będzie przekazać własnym dzieciom.

Losy rodziny opowiadają o historii narodu, a jednocześnie podkreślają jego specyfikę i mentalność. Między wydarzeniami historycznymi dotykającymi naród a zdarzeniami w życiu jednostek zachodzi paralela. Jest to jeden z powodów, dla których nikt nie może zdystansować się od wydarzeń o zasięgu globalnym. Rodziny, które nie mają wśród seniorów rodu byłych zesłańców, również wpisują się w ich doświadczenia, ponieważ same zesłania były konsekwencją wydarzeń historycznych, które objęły cały naród. Traumatyczne wydarzenia dotykające jednostki sąźródłem siły i integralności na poziomie kulturowym, pod warunkiem, że kolejne pokolenia sięgną po wspomnienia rodziców i uczynią je nieodłączną częścią swojej rodzinnej historii. Tajemnice, o których się nie mówi, mogą wpływać na dezintegrację więzi, jeśli wydarzenie zapisało się na tyle boleśnie w pamięci jego bezpośrednich uczestników, że chronią oni swoich bliskich przed wiedzą o nim ${ }^{1}$.

Materiał badawczy stanowią dwa filmy, które są skróconymi relacjami z dwóch podróży na Syberię - w 2011 i 2012 roku², spisane wspomnienia dwójki zesłańców wówczas jeszcze dzieci: Bogusława i Danuty, oraz rozmowa z Dagmarą Żukowską córką Bogusława ${ }^{3}$.

Teoria kulturowych mechanizmów pamięci Jurija Łotmana w połączeniu z koncepcją postpamięci Marianne Hirsch ${ }^{4}$ pozwala umiejscowić wspomnienia rodziny Żukowskich na tle szerszych zjawisk dziedziczenia pamięci kultury z pokolenia na pokolenie. W takim ujęciu jakość i charakter wspomnień mają mniejsze znaczenie niż sam fakt, czy zostaną one włączone w korpus tego, co zapamiętane i przeżyte. Według Hirsch postpamięć ustanawia ponadpokoleniowa przestrzeń pamięci [...] poprzez utożsamienie z ofiarami lub świadkami traumatycznych wydarzeń, jednocześnie zaś warunkowana przez nieprzekraczalny dystans, który oddziela uczestników od tych, którzy urodzili sie już po wydarzeniach ${ }^{5}$. Łotman z kolei zauważa, że każda kultura na różnych etapach swojego rozwoju uaktywnia mechanizmy zapamiętywania pewnego typu zdarzeń, a zapominania wydarzeń innego rodzaju ${ }^{6}$. Niektóre kulturowe doświadczenia o szerokim zasięgu i dużej sile oddziaływania mogą pozostać w swoistym „zawieszeniu” na czas, gdy

1 A.A. Schützenberger, Tajemnice przodków. Ukryty przekaz rodzinny, przeł. B. Łyszkowska, Warszawa 2016, s. 41, Zrozumieć Swiat na Nowo.

2 Drogami pamięci oraz Kromka chleba, prywatny kanał YouTube, [online] www.youtube.com/watch?v=w67fk7DyZY0; www.youtube.com/watch?v=CQ9_35G-dbE, 15 XII 2015.

3 Materiał z rozmowy oraz rękopis wspomnień znajdują się do wglądu u autorki artykułu.

4 M. Hirsch, Family Pictures. Maus, Mourning and Post-Memory, „Discourse” 1992/1993, nr 12.

5 M. Hirsch, Surviving Images. Holocaust Photographs and the Work of Postmemory, „The Yale Journal of Criticism" 2001, Vol. 14, nr 1, s. 10.

6 Ю.М. Аотман, Память в культурологическом освещении, [w:] tegoż, Избранньце статьи, t. 1, Тамлинн, 1992, s. 201. 
działają kody zakazujące ich włączania w korpus tekstów kultury, natomiast otrzymują swoją szansę na wejście do pamięci owej kultury, gdy zaktywizowaniu ulegną inne kody. Freudowskie podejście do traumy, istotne w koncepcji postpamięci Hirsch, w perspektywie łotmanowskiej teorii byłoby interpretowane jako „zawieszenie” włączania do pamięci kultury tekstu ze względu na aktualnie obowiązujące kody, np. warunkowany sytuacją polityczną zakaz mówienia o konkretnych wydarzeniach.

Wspomnienia polskich zesłańców, snute przy rodzinnym stole w czasie powrotów na Syberię - jak w przypadku Bogusława i jego rodziny, czy wydawane jako monografie, stanowią włączenie do pamięci kultury wydarzeń, które w momencie zaistnienia zostały zmarginalizowane ze względu na obowiązujące wówczas mechanizmy kultury. Wymiar jednostkowy wspomnień, nierozerwalnie związany z aspektem historii kraju i narodu, zostaje włączony do dziedzictwa kultury poprzez powiązanie osobistych doświadczeń z faktami dotyczącymi losów całego narodu.

\section{WYSPY PAMIĘCI - LOSY RODZINY ŻUKOWSKICH NA ZESŁANIU}

Losy zesłanej rodziny układają się w pewnego rodzaju wyspy, wyodrębnione na podstawie poszczególnych etapów zesłania - od wysiedlenia z rodzimej Hajnówki po ponowne przekroczenie granicy z Polską po sześciu latach tułaczki po syberyjskiej tajdze. Cezury owego okresu stanowią dwie daty: noc z 9 na 10 lutego 1940 roku, kiedy miało miejsce wysiedlenie, oraz dzień 22 marca 1946 roku - powrót do Polski. Tę pierwszą, traumatyczną datę wspomina Danuta, wówczas siedmioletnia: Dzień 10 lutego zaczątsię dla nas bardzo wcześnie, tuż po pótnocy. Wtedy przyszli po nas sowieccy żotnierze. Najpierw oddali dwa strzaty. To byto pierwsze co zrobili. Strzelili do psa, Lalka, pilnującego obejścia. [...] Rozpoczęta sie rewizja, prowadzona chaotycznie, na oślep. Porozwalali wszystko. Jakby nie wiedzieli, czego szukaja. [...] Wtaśnie wtedy zabrano nam bezpowrotnie bezcenne wspomnienia pierwszych, tak szczęśliwych lat naszego dzieciństwa. Do tego utraconego świata Danuta będzie wracać we wspomnieniach w dalekiej tajdze: Przeniostam się w myślach, w wyobraźni do mojej cudownej Hajnówki. Robitam tak zawsze już od początku [...] gdy robito mi się smutno, gtodno igdy nie mogtam siępogodzić z realiami naszego zestania. Wnoc zestania dzieci nie ptakaty; częściowo wskutek szoku, a czę́siowo dlatego, że nasza Jadzia wyszeptata: „Nie ptaczcie, bo wrogowie będą się cieszyc'". Więc my robiliśmy wszystko, żeby nie ptakać.

O drugiej dacie bohaterka wspomnień mówi tak: Jak przyjechaliśmy do Przemyśla i jak wysiedlismy, to wszyscy catowali ziemie - Polska Ziemię. I wszyscy od razu poszli do kościota. Nieważne, czy się ktoś modlit, czy nie modlit, czy byt wierzacy, czy też nie - wszyscy poszli do kościota. Zadajmy sobie pytanie, co działo się na przestrzeni owych sześciu lat pobytu nie tyle na obcej, ile - mówiąc słowami Józefa Czapskiego - nieludzkiej ziemi ${ }^{7}$.

Pierwsza wyspa pamięci to trwająca prawie dwa miesiące podróż towarowymi wagonami: nieogrzewanymi, zatłoczonymi do granic możliwości, pełnymi insektów. Bardzo złe warunki sanitarne, skąpe racje żywnościowe, brak wody, a także szok, w jakim

J. Czapski, Na nieludzkiej ziemi, Kraków 2001. 
pozostawało wielu podróżujących, powodowały dużą śmiertelność. Nawet po latach trudno wyrazić słowami ogrom nieszczęścia, jakie spadło na zesłańców, i przerażenia, które stało się ich udziałem. Wówczas jedynym środkiem wyrazu była cisza: Myślatam tylko o tym, że ta cisza na samochodzie zwiastuje coś potwornego. Ona byta niestyszalnym krzykiem, jakaś niewykrzyczana skarga. Trauma skutkuje białymi plamami, lukami w pamięci: I tu urywaja się moje wspomnienia, tak jakby dalszej drogi już nie byto. Te plamy zostaną później zapełnione dzięki wspomnieniom innych członków rodziny, jednak w tamtej chwili odcięcie się od rzeczywistości było warunkiem psychicznego przetrwania.

Kolejna wysepka pamięci łączy się z malutką osadą (pasiołkiem) o nazwie Gramatucha, nad rzeczką o tej samej nazwie, będącą dopływem większej rzeki: Kiji. Komendant obozu zwołał zesłańców: Wy tu będziecie żyćpo wszystkie czasy i Polski już nie zobaczycie. Wy jesteście dumne polskie pany, ale tu będziecie żyć i pracować tak jak my wam każemy. Wspomnienia okoliczności zakwaterowania i przypieczętowania losu zesłańców przeplatają się ze wspomnieniami reakcji dzieci na nowe miejsce. Mówi Danuta: $W$ dzieci [...] nagle wstapit szalony duch, odzyskaty sity witalne, zapominajac o zmęczeniu przebytej drogi. Zaczęta się szaleńcza zabawa: „Będziemy tak zaznaczać tu nasza polska obecnośc" - zawotata [Jadzia], padając plecami w śnieg i ruszając energicznie szeroko rozpostartymi rękoma. Pracowicie wyznaczata jeden za drugim ślad skrzydet "polskiego orta”.

Dziecięca radość i beztroska szybko jednak zderzyły się z okrutną rzeczywistością zesłania: chorobami, zimnem, głodem, ciężką pracą i śmiercią. To elementy, które łączą wysepki pamięci i odciskają niezatarte piętno na wszystkich momentach, również tych przyszłych, życia dzieci. Jeszcze jeden element towarzyszy im nieustannie - patriotyzm, przejęty od rodziców, a wyrażany niewypowiedzianą nadzieją powrotu do Polski. Danuta wspomina: Byta Wielkanoc 1941 roku. [...] Dobrze zapamiętatam Wielki Piatek. W tym dniu mama jakby przekazywata nam swój testament. W kazdej modlitwie czy rozmowie mamusia powtarzata: „Pamiętajcie, że jestéście Polakami, pamiętajcie!". Ale tego dnia rozwinęta swoje myśli. Już wtedy się batam, że mamusia to mówi, bo wie, że umrze.

Pamiętajcie, że jesteście Polakami - powraca we wspomnieniach jak refren. Śmierć towarzyszyła dzieciom bez przerwy. Danuta wspomina: Jedna kobieta poszta do komendanta, ttumaczyta i prosita, że matka jej jest w agonii i lada chwila może umrzeć. Zaklinata go, aby pozwolit jej zostać przy matce i zwolnit z pracy. Komendant nie zgodził się i przy umierającej babci czuwały dzieci, które same miały rozstrzygnąć, czy babcia już umarła, i rozprostować jej nogi.

Z okresem pobytu w osadzie Gramatucha wiąże się zjawisko „pamięci uzupełnionej” Bogusława. Miał wówczas niecałe cztery latka i nie do końca zdawał sobie sprawę ze stanu zdrowia mamy: już w momencie zesłania jej stan zdrowotny nie był najlepszy, a uległ pogorszeniu po niefortunnym upadku na śliskiej ścieżce z Udarnoje do Gramatuchy - tam Sylwestra Żukowska chodziła z córką Jadwigą do lekarza. Danuta mówi: Ja mam przekonanie, że od tego wydarzenia ze zdrowiem mamy zaczęto się dziać cośnaprawdęztego, natomiast Bogusław zauważa: Trudno mi ocenić wptyw tego wydarzenia na zdrowie mamy. Historii tej nie znatem. Stan zdrowia Sylwestry niezmiennie pogarszał się i 16 lipca 1941 roku zaczęła umierać. W nocy obudzono dzieci, by się z nią pożegnały. 
Bogusław skończył właśnie pięć lat. Na wieść, że mama umiera, podniósł ogromny lament i - po latach wspomina - dorośli w żaden sposób nie mogli okietznać tego lamentu. Wtedy wydarzyto się cośniezwyktego: proces agonii zostat przerwany, a mama nie umarta tej nocy. Sylwestra zmarła trzy noce później, ale wówczas małego Bogusia już nie budzono: Boguśz znowu nie da jej odejść - tak powiedziaty żegnające mamę kobiety. Bogusław po latach wspomina z żalem: Odeszta... Ja jeden się z nią nie pożegnatem... Właśnie ów brak pożegnania stanie się po 70 latach głównym impulsem do powrotu na Syberię - by odnaleźć grób mamy, zapalić świeczkę i w ten symboliczny sposób pożegnać się z nią. Ta chęć pożegnania mamy trwała w Bogusławie przez całe jego życie. Śmierć Sylwestry była na tyle traumatycznym przeżyciem, że stworzyła kolejną białą plamę na mapie wspomnień. Nie rozmawiano o przyczynach, chociaż każdy o nich myślał. Bogusław mówi: Po wojnie nigdy nie rozmawialiśmy z ojcem na temat śmierci mamy i jej przyczyn.

Syberyjskie warunki to także odwrócenie świata wartości dziecka: z jednej strony bezwarunkowa pomoc i wzajemne wspieranie się zesłańców, a z drugiej - konieczność kłamania i ukrywania prawdziwych uczuć. Ojciec Bogusława i Danuty podał nieprawdziwe daty urodzin dzieci, by uchronić je i żonę przed koniecznością natychmiastowego podjęcia ciężkiej pracy: [Tatuś] powiedziat Jadzi, że ma mniej lat i żeby tak w szkole wszystkim mówita. Zrobit to bardzo po cichutku, ale ja to styszatam i bardzo sięzdziwitam: dlaczego Jadzia ma ktamać?! Przecież to tata zawsze mówit, że ktamać nie wolno.

Kolejna wyspa pamięci to Buzułuk. Tu ojciec Bogusława wstąpił w szeregi nowo tworzonej armii gen. Andersa i otrzymał zadanie odszukania polskich dzieci w radzieckich domach dziecka. Nie było to zadanie łatwe, ponieważ władze radzieckie nie pomagały, a dzieci często były zaszczute i pełne obaw, że stracą ten jedyny dach nad głową, jaki mają. Leonard zdobywał zaufanie dzieci, szepcząc: Aniele Boży, Stróżu mój... Bogusław wspomina: Ty zawsze przy mnie stój - kiedy dziecko po cichutku, prawie niedostyszalnie, odpowiadato mu, miat pewność, że jest ono polskie. Nadzieja na rychly powrót do ojczyzny w rezultacie rozpoczętej przez hitlerowskie Niemcy wojny z ZSRR i podpisanie układu Sikorski-Majski okazała się płonna. Władze radzieckie pragnęły zatrzymać „niebezpieczny element" u siebie. Ojca Bogusława próbowano zmusić do przyjęcia radzieckiego obywatelstwa, a gdy odmówił - aresztowano go i zesłano do łagru. Danuta wspomina: Nasz ojciec nieustannie odmawiat przyjęcia tego "nowego" dokumentu. Liczyt się więc z tym, $\dot{z}$ e będzie poddany represjom. Mimo że miat pod opieka nas - czworo nieletnich dzieci - byt Polakiem, bytym legionista i widocznie ztamać się nie potrafit. Danuta uzupełnia: To znamienne, legioniści mieli zakodowane, że lepsza śmieć niz hańba. Jeśli wyrzekteśsię swojej narodowości, swojej ojczyzny, to byto to równoznaczne z wyrzeczeniem siępolskości, naro$d u$, ukochanego kraju. Osierocone dzieci trafiły, dzięki szczęśliwemu zbiegowi okoliczności i fortelowi wymyślonemu przez mieszkańców Buzułuka, pod opiekę Polki, Marii Stolarczyk. Wspomnienia z przebiegu aresztowania również należały do tych, których dzieciom oszczędzano. Bogusław mówi: Kiedy potem dociekaliśmy prawdy u taty o jego aresztowaniu, to on próbowat oszczędzić nam opowieści z przebiegu przestuchań, jak i tych późniejszych, z pobytu w tagrze. Wiem jednak od ojca, że pozostawianie nagiego cztowieka, bez prawa do jedzenia i picia, w zimnej zawilgoconej norze, gdzie ściany byty pokryte zmarzlina, byto jednym z tagodniejszych sposobów przekonywania do sowieckiego obywatelstwa. 


\section{MIĘDZY ZAPOMNIENIEM A PRZYPOMINANIEM SOBIE}

Przypominanie sobie wymagało przekroczenia wielu barier: zarówno tych wewnętrznych, psychologicznych, chroniących przed bólem przeżytej traumy, jak i zewnętrznych, uwarunkowanych realiami politycznymi kraju w sowieckiej orbicie wpływów. Wymagało też stworzenia przestrzeni - czyli obecności życzliwych ludzi, nie tylko zainteresowanych losem dawnych zesłańców, ale także wystarczająco silnych i odważnych, by znieść dzielenie się bólem. Wreszcie wymagało wyruszenia w drogę - zarówno w sensie przenośnym, jak i dosłownie. Według słów Dagmary pomysł podróży na Syberię pojawił się niespodziewanie: Na spotkaniu rodzinnym mówiliśmy - zupetnie przypadkiem - o marzeniach i potrzebie ich spetniania. O różnych mówitam ja, siostra, mama - wszystkie nasze związane byty z „teraźniejszościa." A ojciec dtugo siedziat jakby nieobecny, po czym powiedziat, że zawsze miat $w$ życiu jedno marzenie, które nigdy się nie spetni. Chciat zapalić - raz jeden jedyny - znicz na grobie swojej matki. [...] Przygotowania zajety ponad rok, zapewne mogtyby zając mniej czasu, ale świadomie już przy podejmowaniu tej decyzji ojciec wskazat date70. rocznica śmierci matki - to zdefiniowato tak naprawdę czas przygotowań.

Podróż na Sybir stała się podróżą w przeszłość, a także okazją, by doświadczeniu rodziców dać należne im miejsce w historii rodziny. We wcześniejszych wspomnieniach zesłanie było tematem podejmowanym niechętnie i bardzo ostrożnie. Z wątków, które pojawiały się w rozmowach, gdy starsze już dzieci zaczęły dopytywać rodziców o ich przeszłość, Dagmara pamięta ten o babci Sylwestrze: Wszystkie dzieci miaty dwie babcie, a ja tylko jedna, tę ze strony mamy. Matka ojca zmarta na Syberii. To wiedziatam, ale dlaczego - tego już nikt nie chciat mi wyjaśnić, jak i tego, dlaczego i jak oni się tam z cata rodzina znaleźli.

Drugi temat, który bywał pomijany w codziennych rozmowach i dopiero rozległa przestrzeń Syberii spowodowała, że pojawił się on w rozmowie, to temat głodu i nierozerwalnie z nim związanego szacunku do chleba. Zastanawiający jest fakt, że trudno było mówić o tak traumatycznym przeżyciu przy zastawionym stole, $\mathrm{w}$ atmosferze dobrobytu. Na zakończenie filmu Kromka chleba Bogusław mówi: To, czego nauczyta mnie Syberia, to szacunek dla kromki chleba. Dzielenie się chlebem i troska w najtrudniejszych warunkach stanowiły sprawdzian człowieczeństwa i miłości - uczucia, które sięgało do samego sedna ludzkiej natury, ponieważ sprawdzało się w działaniu, w walce o przetrwanie.

Wśród wspomnień pojawiały się też opowieści o zdarzeniach zabawnych z punktu widzenia dziecka, śmiesznych lub dowodzących odwagi czy bohaterstwa samych dzieci - ale, jak zauważa Dagmara: Z próba pominięcia lub bagatelizowania istotnych szczegótów. Zawsze w którymśmomencie tych opowieści wychodzito widmo tego, co chcieli ukryć (gtód, ziąb, śmierć matki, zostanie bez środków do życia po aresztowaniu ojca). Realna podróż nasunęła pytania, które można było zadać ojcu na temat jego wczesnego dzieciństwa, ale przede wszystkim owa podróż stworzyła przestrzeń dla umocnienia więzi międzypokoleniowej.

Dagmara dodaje: $W$ trakcie podróży mielismy dużo czasu, bez codziennej gonitwy i codziennych spraw, można byto szczegótowo o wszystko dopytać, cata historię dogtębnie 
poznać, zapamiętać, zrozumieć. A ojciec, widzac szczere zainteresowanie, też oddat się wspomnieniom, otworzyt się, rozgadat. To byt duży wysitek i z mojej strony, żeby nie prześlizną́ się po temacie, żeby się $w$ to wtopić. Pomogto bardzo obcowanie z miejscami tamtych wydarzeń, pozwolito niemal dotknać pozostatości z tamtych lat, uruchomić wyobraźnię, wręcz poczuć tamte dni. Rezultat podróży byt zaskakujacy; uważam, że nie tylko poznatam i zrozumiatam dogtębnie traume dziecinstwa mojego ojca, myśle, $\dot{z} e$ pomogtam mu w jakiejśs czéści - chyba dużej - z nią się uporać. Wspólną podróż na Syberię, możliwość powrotu pamięcią do tamtych zdarzeń można potraktować jako inicjację - włączenie pokolenia dzieci w życie przodków. Zarówno ojciec, jak i ciocia niezmiernie sa nam - mnie i mojemu mężowi - wdzięczni, że podjęliśmy trud odnalezienia mogity ich matki, że byliśmy tam, postawiliśmy krzyż, zapaliliśmy świece. [...] Traktuja nas - jak swoich, tych wtajemniczonych, tych, co wiedza, o co chodzi, co czuja i rozumiejąich ból.

Dobro pamięci jest wtajemniczeniem pokolenia dzieci i wnuków w historię rodziny, wraz z całym bagażem jej doświadczeń; swoistym włączeniem wszystkich członków we wspólny los. Syberyjskie doświadczenia przodków, przeżyte wraz z nimi ponownie w trakcie opowieści, stają się mechanizmem łączenia pokoleń, zachowywania dziedzictwa kulturowego i umacnianiem kulturowych korzeni młodych pokoleń. Świadomość, że nasi przodkowie $\mathrm{w}$ tak trudnych warunkach zdołali przeżyć i z bagażem doświadczeń śmierci, głodu i zimna wychować dzieci, dając im to, co mieli najlepsze, rodzi poczucie wyjątkowej siły i godności.

W takim ujęciu „postpamięć” nie jest jedynie zbiorem wspomnień, przekazanych w niedoskonały i niedokładny sposób pokoleniom dzieci. Nie służy też odbyciu, odroczonej w czasie, żałoby po przeżytej traumie. Staje się ona mechanizmem dziedziczenia pamięci kultury oraz oswajania traumy, by na jej fundamencie zbudować trwały system nieprzemijających wartości, wyrażonych w szacunku dla drugiego człowieka; w poszanowaniu „kromki chleba”.

Dagmara wspomina: Gdy dorośli "wchodzili na temat", a zauważali, że stuchaja tego dzieci, rozmowy te byty natychmiast urywane, a nasze pytania zbywane. [...] Ale dziśwydaje mi się, że wiedziatam o „ich Syberii”, od kiedy siegnę pamięcia [...]. Ciekawskim powoli mówiono szerzej, bardziej szczegótowo. Pojawiaty się wtedy nowe informacje i nowe opowieści. Dotyczyty przede wszystkim zdarzeń historycznych, faktów czy ogólnych zasad życia na zestaniu. One pozwalaty nam zrozumieć zależność przyczynowo-skutkowa tego, co przeżyli, co się wydarzyto. Te wyjaśnienia ujawniano nam bardzo niechętnie, z dużym oporem, raczej zawsze byty bolesne, a na dodatek „niepoprawne” politycznie w stosunku do obowiazujacej oficjalnie doktryny. Ten ostatni powód, mam wrażenie, byt decydujacy. Tak dtugo, jak tylko mogli, próbowali nas chronić.

Córka Bogusława podkreśla, że chciałaby przekazać historię w najdrobniejszych szczególach także swojej córce. Wyraża też nadzieję na zaangażowanie z jej strony. $\mathrm{Na}$ pytanie: „dlaczego?”, odpowiada: Dlaczego to ważne? Bo w tej opowieści - o ile zdobyć się na refleksje - zapisane sa najważniejsze wartości: cztowieczeństwo, wiara, wytrwatość, walka o przetrwanie... Najistotniejsze sa jednak korzenie, skąd się wywodzimy, świadomość przodków daje zrozumienie i siłę. 


\section{WNIOSKI}

Losy jednej rodziny stanowią odzwierciedlenie doświadczenia wielu rodzin ze względu na wydarzenia historyczne, które objęły swoim zasięgiem ogromne terytorium geograficzne. Ważniejszy jednak jest sposób pamiętania o traumie i dzieleniu się nią z dziećmi, wnukami, a za ich pośrednictwem - ze społeczeństwem. Sybir Bogusława Żukowskiego i jego siostry Danuty jest miejscem tragicznych wydarzeń, które położyły się cieniem nie tylko na losach rodzeństwa, ale także ich dzieci. Warto jednak zauważyć, że Sybir był również miejscem, gdzie kształtowały się i umacniały podstawowe wartości: solidarność, wzajemna troska, szacunek dla ciężkiej pracy i dla chleba, który w tym przypadku symbolizuje nie tylko możliwości przeżycia dzięki pożywieniu, ale także - stanowi wyraz człowieczeństwa; tego, co najlepsze w ludzkiej naturze: zdolności do dzielenia się podstawowym dobrem. We wspomnieniach Bogusława i Danuty, a następnie - w ich odbiorze przez Dagmarę, przez historię ciężkiego losu zesłańców przebija wiara w człowieka i gorące umiłowanie życia jako największej wartości.

Postpamięć w tym przypadku staje się narzędziem afirmacji życia w każdym z jego przejawów i w każdych, najcięższych nawet warunkach.

\section{BIBLIOGRAFIA}

Czapski J., Na nieludzkiej ziemi, Kraków 2001.

Hirsch M., Family Pictures. Maus, Mourning and Post-Memory, „Discourse” 1992/1993, nr 12. Hirsch M., Surviving Images. Holocaust Photographs and the Work of Postmemory, „The Yale Journal of Criticism" 2001, Vol. 14, nr 1, [online] https://doi.org/10.1353/yale.2001.0008. Schützenberger A.A., Tajemnice przodków. Ukryty przekaz rodzinny, przeł. B. Łyszkowska, Warszawa 2016, Zrozumieć Świat na Nowo.

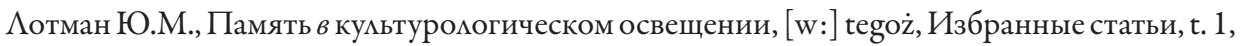
Талминн 1992.

Dr hab. Małgorzata ABASSY - kulturoznawca i literaturoznawca, kierownik Zakładu Nowożytnej Kultury Rosyjskiej i Teorii Systemów Kulturowych w Instytucie Rosji i Europy Wschodniej na Wydziale Studiów Międzynarodowych i Politycznych Uniwersytetu Jagiellońskiego w Krakowie. Zajmuje się stosunkami polsko-rosyjskimi oraz rosyjsko-polskimi w ujęciu systemowym, przez pryzmat mentalności, języka jako nośnika tożsamości oraz teorii komunikacji. Bada teksty literackie jako nośniki treści kulturowych w kulturach literaturocentrycznych. Autorka czterech monografii: Russian Mason on the Paths of his Native Culture. The Case Study of Nicolas Novikov (2014), Kultura wobec postepu i modernizacji. Rosja i Iran wperspektywieporównawczej (2013), Irańska inteligencja w XIX wieku i Rewolucja Konstytucyjna (1905-1911) (2010), Inteligencja a kultura. O problemach samoidentyfikacji dziewiętnastowiecznej inteligencji rosyjskiej (2008). Członek Societas Iranologica Europea, Komisji Kultury Słowian Polskiej Akademii Nauk oraz Polskiego Towarzystwa Kulturoznawczego. 